Revista Eletrônica Geografar, Curitiba, v. 2, Resumos do VI Seminário Interno de Pós-Graduação em Geografia, p. 42-42. Junho/2007

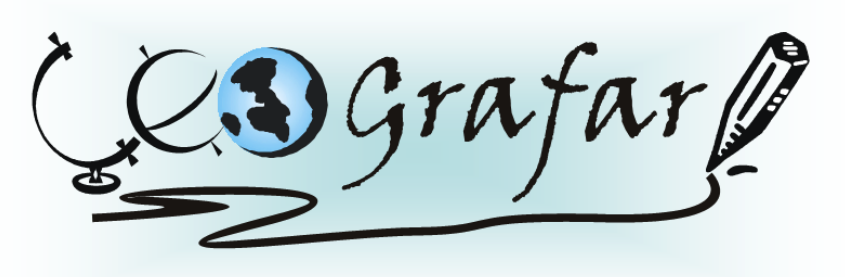

Revista Eletrônica do Programa de Pós-Graduação em Geografia - UFPR

\title{
AVALIAÇÃO E CLASSIFICAÇÃO DA ERODIBILIDADE DOS SOLOS DO NOROESTE DO ESTADO DO PARANÁ: SUBSÍDIO AO USO E OCUPAÇÃO DA TERRA
}

\section{LAIANE ADY WESTPHALEN ${ }^{1}$}

O noroeste do estado do Paraná caracteriza-se por apresentar processos acelerados de erosão hídrica na qual comprometem estradas, áreas urbanizadas e agrícolas, trazendo prejuízos sociais, econômicos e diminuindo a capacidade produtiva dos solos. O fluxo superficial da água da chuva, de acordo com o escoamento, produz formas de erosão diferenciadas, como a erosão laminar (remoção aparentemente uniforme da camada superior do solo) e a erosão linear (remoção de sedimentos pelo fluxo concentrado da água superficial ou de sub-superfície) (GUERRA, 1999). No entanto, de acordo com as características físicas e morfológicas, os solos apresentam capacidades distintas de resistência a ação da água e aos processos erosivos, sendo denominadas de erodibilidade (BERTONI, 1990). Desta forma, utilizando informações disponibilizadas no Levantamento de Reconhecimento dos Solos do Estado do Paraná (EMBRAPA, 1984), pretende-se propor uma classificação da erodibilidade dos solos do noroeste do Estado. Para classificação foram considerados sete parâmetros: Profundidade, Horizonte A, Horizonte B, Textura, Silte/Argila, Floculação e Proporção Areia, Silte e Argila. Como resultados preliminares classificou-se a resistência dos solos a erosão laminar nas classes: Baixa, na qual inclui-se os Latossolos Vermelhos, A moderado e A chernozêmico, textura argilosa, alta floculação, elevada intemperização e baixa proporção de areia. Na classe Média estão os Nitossolos, A moderado, textura argilosa, alto grau de intemperização e baixa proporção de areia, o diferencial está na baixa floculação nos horizontes superficiais. Na classe Alta estão os Neossolos Litólicos, A chernozêmico, textura média e argilosa. E na Elevada incluiu-se os Argissolos Vermelho-Amarelo, com mudança textural abrupta, baixa floculação, alta proporção de areia. Os Latossolos Vermelho, textura média e arenosa, alta proporção de areia, e os Neossolos Quartzarêmicos, com alta proporção de areia. Por fim, as informações da Embrapa estão sendo fundamentais para uma avaliação ampla das características do solo permitindo a extrapolação para a área de estudo selecionada.

Palavras-chave: Solos, Erodibilidade, Noroeste do Paraná.

${ }^{1}$ Mestranda em Geografia - UFPR - email:laianeaw@yahoo.com.br Orientador:LEONARDO JOSÉ CORDEIRO SANTOS 